\title{
INDICATION FOR BLOOD TRANSFUSION IN EMERGENCY DEPARTMENT OF A TERTIARY CARE CENTRE
}

\author{
Ramesh Gorghatta Hanumanthaiah1, Panchakshari Prasanna Bangalore Krishnappa², Dheemantha Prasad³, Sreelatha $R^{4}$
}

${ }^{1}$ Associate Professor, Department of Accident and Emergency Medicine, Bangalore Medical College and Research Institute (BMCRI). ${ }^{2}$ Associate Professor, Department of Transfusion Medicine, Bangalore Medical College and Research Institute (BMCRI), Bangalore. ${ }^{3}$ Assistant Professor, Department of Transfusion Medicine, Bangalore Medical College and Research Institute (BMCRI), Bangalore. 4 Professor, Department of Transfusion Medicine, Bangalore Medical College and Research Institute (BMCRI), Bangalore.

ABSTRACT
BACKGROUND
Blood usage in the emergency department is a formidable challenge to the treating doctor. Inadvertent use of blood can do more
harm to the patient than good. Analysing blood transfusion data will help in formulating policies for transfusion in Emergency
Medicine Department.
Aims and Objectives- The present study is taken to formulate guidelines for transfusion in Emergency Department of our hospital.
The present study also helps us to analyse the blood requirement, utilisation and wastage in Emergency Department, Victoria
Hospital.

\section{MATERIALS AND METHODS}

The study done was a prospective study over a period of three months from March 2016 to May 2016. A descriptive, prospective study was conducted with a total of three hundred cases collected from the Emergency Department (Casualty), Victoria Hospital.

\section{RESULTS}

Commonest indication for packed red cell transfusion was anaemia, for FFP was hypoproteinaemia and for platelet concentrate was viral haemorrhagic fever.

Discussion- Transfusion trigger for packed red cells is haemoglobin of less than 7 grams/dL with no co-morbid conditions and 7 - 9 grams/dL when there are co-morbid conditions.

\section{CONCLUSION}

A protocol must be formulated to reduce the wastage and to effectively utilise blood and its products.

\section{KEYWORDS}

Transfusion, Packed Red Cells, Fresh Frozen Plasma, Platelet.

HOW TO CITE THIS ARTICLE: Hanumanthaiah RG, Krishnappa PPB, Prasad D, et al. Indication for blood transfusion in emergency department of a tertiary care centre. J. Evolution Med. Dent. Sci. 2017;6(29):2346-2348, DOI: 10.14260/Jemds/2017/505

\begin{abstract}
BACKGROUND
Transfusion of blood and its products form one of the important pillars in the treatment of a patient in emergency department. Blood usage in the emergency department is a formidable challenge to the treating doctor. Inadvertent use of blood can do more harm to the patient than good. 1 This can lead to financial and medical burden to the patient. Analysing the data will help in formulating policies for transfusion in Emergency Medicine Department. This is part of the haemovigilance program, ${ }^{2}$ which is required to identify and prevent occurrence of transfusion related unwanted events due to inadvertent use of blood and blood products.

The present study is taken to formulate guidelines for transfusion in emergency department of our hospital. The most commonly utilised blood product in emergency department is packed red blood cells. ${ }^{3}$
\end{abstract}

Financial or Other, Competing Interest: None.

Submission 03-03-2017, Peer Review 26-03-2017,

Acceptance 02-04-2017, Published 10-04-2017.

Corresponding Author:

Dr. Dheemantha Prasad,

No 31/2, $18^{\text {th }}$ Main Road,

A.G.S Layout,

Bangalore- 560061.

E-mail: dheemanthap@gmail.com

DOI: $10.14260 /$ jemds $/ 2017 / 505$
The common indications for transfusion of packed red cells being acute blood loss. Based on the percentage of blood lost requirement of packed red blood cells also varies. Anaemia is also quite common indication in the developing nations. Also heart failure is commonly associated with Anaemia. ${ }^{4}$ Transfusion of packed red cells in the children is done at a rate of $10-20 \mathrm{~mL} / \mathrm{kg} / \mathrm{hr}^{5}$ Massive transfusion is also commonly done in the Emergency department in road traffic accidents and is associated with complications like hypothermia and hypocalcaemia. ${ }^{6}$ One unit of packed red cells transfused will increase the haemoglobin by one gram per dL and Haematocrit by three percent. ${ }^{7}$ Packed red blood cells are prepared by centrifuging whole blood and separating red cells. In uncomplicated anaemia, transfusion trigger is 7 $8 \mathrm{gm} / \mathrm{dL}^{8}$; however, it is largely to the discretion of the treating doctor to change the trigger based on the comorbidities of the patient.

Fresh frozen plasma is indicated in patients with liver failure, ${ }^{9}$ warfarin overdose, disseminated intravascular coagulation and thrombotic thrombocytopaenic purpura. One unit of Fresh frozen plasma contains one unit of coagulation factor and $1 \mathrm{~mL}$ of FFP contains 2 units of Fibrinogen.

Platelet concentrates are used in a variety of diseases, which manifests as low platelet count ${ }^{10}$ or thrombasthenia. Viral fevers especially from dengue have become a quite common indication for platelet transfusion in India. ${ }^{11}$ 
In all transfusions, there will be chance of transfusion transmitted diseases, allergic reaction and other forms of transfusion reactions leading to increased mortality and morbidity in the patients.

The present study aims at analysing the blood requirement, utilisation and wastage in Emergency department.

\section{Aims and Objectives}

1. To frame guidelines for transfusion in Emergency department patients of Victoria Hospital, BMCRI.

2. To analyse the blood requirement, utilisation and wastage in Emergency department, Victoria Hospital, BMCRI.

\section{MATERIALS AND METHODS}

The study done was a prospective study over a period of three months from March 2016 to May 2016. A total of three hundred cases were collected from the Emergency department (Casualty), Victoria Hospital. This is a descriptive study. All acute cases receiving blood transfusion admitted under Emergency department, Trauma Centre, Victoria Hospital were included in the study.

\section{Exclusion Criteria}

1. Patients who were recently blood transfused before being admitted to emergency department.

2. Severe Left ventricular dysfunction with Ejection fraction of less than $30 \%$.

Statistical analysis was done by means of Descriptive statistics like mean, standard deviation, percentages and inferential statistics like Chi-Square test.

\section{RESULTS}

Out of the total 300 cases included in the study, 180 cases were males and 120 cases were females.

Out of the total 300 patients, 136 patients required only packed red cells. Out of these 136 patients, 86 were males and 50 were females. The common indications for packed red cell transfusion in the casualty were anaemia and acute blood loss.

\begin{tabular}{|c|c|c|}
\hline $\begin{array}{c}\text { Indications for } \\
\text { Packed Red Cell } \\
\text { Transfusion } \\
\end{array}$ & $\begin{array}{c}\text { Number of Male } \\
\text { Patients } \\
\text { Transfused } \\
\end{array}$ & $\begin{array}{c}\text { Number of } \\
\text { Female Patients } \\
\text { Transfused } \\
\end{array}$ \\
\hline Anaemia & 56 & 30 \\
\hline Acute blood loss & 21 & 14 \\
\hline Others & 09 & 06 \\
\hline Total & 86 & 50 \\
\hline
\end{tabular}

Out of the 300 patients, 55 were transfused with only fresh frozen plasma. Hypoproteinaemia and Alcoholic liver disease were the commonest indications for transfusion of FFP. Third space loss, nutritional anaemia and prolonged bed ridden patients who suddenly developed intercurrent infections were also treated with FFP.

\begin{tabular}{|c|c|c|}
\hline $\begin{array}{l}\text { Indications } \\
\text { for FFP } \\
\text { Transfusion }\end{array}$ & $\begin{array}{l}\text { Number of } \\
\text { Males } \\
\text { Transfused }\end{array}$ & $\begin{array}{l}\text { Number of } \\
\text { Females } \\
\text { Transfused }\end{array}$ \\
\hline Hypoproteinaemia & 15 & 11 \\
\hline Alcoholic liver disease & 07 & 05 \\
\hline 3rd Space Loss & 05 & 04 \\
\hline Nutritional Anaemia & 03 & 02 \\
\hline $\begin{array}{l}\text { Critical illness/ } \\
\text { Prolonged bed } \\
\text { ridden patients }\end{array}$ & 02 & 01 \\
\hline Total & 32 & 23 \\
\hline
\end{tabular}

Out of the 300 cases which required transfusion, 48 cases required platelet concentrate. Majority of patients requiring platelet concentrate transfusion were suffering from viral haemorrhagic fever. Some patients with thrombocytopaenia with other causes were also transfused with platelet concentrate.

\begin{tabular}{|c|c|c|}
\hline $\begin{array}{c}\text { Indications for } \\
\text { Platelet Concentrate } \\
\text { Transfusion } \\
\end{array}$ & $\begin{array}{c}\text { Number of Males } \\
\text { Transfused }\end{array}$ & $\begin{array}{c}\text { Number of } \\
\text { Females } \\
\text { Transfused } \\
\end{array}$ \\
\hline $\begin{array}{l}\text { Viral haemorrhagic } \\
\text { fever }\end{array}$ & 34 & 11 \\
\hline $\begin{array}{l}\text { Thrombocytopaenia } \\
\text { due to other causes }\end{array}$ & 04 & 01 \\
\hline Total & 38 & 12 \\
\hline
\end{tabular}

61 cases had diseases which required more than one component for their treatment. These cases were Massive blood transfusion, Alcoholic liver disease with Anaemia and Altered coagulation profile with Thrombocytopaenia; 38 cases required massive transfusion with all the blood components including packed red cells, FFP and platelet concentrate. Patients suffering from alcoholic liver disease with anaemia of Haemoglobin less than $7 \mathrm{~g} / \mathrm{dL}$ were transfused with both packed cells and FFP. Some diseases coexisted which required packed cells, FFP and platelet concentrate to be given in various combinations.

147 units of packed red cells were given to 35 patients having acute blood loss. Acute blood loss required more units to be transfused to the patients on an average than other indications. On average patients with acute blood loss received 4.2 units of blood per patient as compared to anaemia, which required 2.5 units of packed cells to be transfused to the patient; 86 patients suffering from anaemia had an average transfusion of 2.5 packed cells per patient which accounted to 215 blood units.

22 units of packed cells remained unutilised, as some had reactions and others did not require further transfusion.

Out of the 55 patients requiring FFP, most of them required multiple units of FFP. Each patient required 6.6 units of FFP on an average; 363 units of FFP were utilised and 15 units remained unutilised.

All the patients requiring platelets received random donor platelets only. Each patient received an average of 8.5 units of platelet concentrate; 16 units of platelet concentrate remained unutilised.

Haemoglobin of $7 \mathrm{~g} / \mathrm{dL}$ was taken as a trigger to transfuse packed cells in anaemia. When anaemia was associated with 
other co-morbid conditions, this trigger was increased based on the condition of the patient.

\section{DISCUSSION}

In our study the commonest indication for packed red cell transfusion was Anaemia, which accounted for 86 cases of the total 300 (28.6\%). S Yaddanapudi et al conducted a study, which also showed that the commonest indication for blood transfusion for packed red cells was anaemia.

In our study the transfusion trigger was 7 grams/dL, which is found to be similar to the other studies conducted by $S$ Yaddanapudi et al in patients who did not have other comorbid conditions. In patients having co-morbid conditions, blood transfusion was started at 7 - 9 grams/dL. Acute blood loss was the most common indication for multiple blood transfusions and multiple component transfusions.

Carson JL et al 12 in their study also found out that the indication for blood transfusion in anaemia is $7 \mathrm{grams} / \mathrm{dL}$ in patients having no co-morbid conditions.

The most common indication for platelet transfusion was viral haemorrhagic fever and required multiple units of platelet concentrate transfusion, which was similar to other studies done by Sharma $S$ et al. Average number of packed red cell units transfused to a patient suffering from acute blood loss was 4.2 , which was similar to the number of units transfused to patients studied by Stanley et al which was 3.9 units.

Alcoholic liver disease with anaemia and altered coagulation profile with thrombocytopaenia required packed cells, FFP and platelet concentrate in different proportions. These were also the commonest indications in our study and the study conducted by S Yaddanapudi et al.

In our study, patients receiving Platelet concentrate used more than 6 units on an average per patient. In the study conducted by Carson JL et al, the number of random donor platelets used per patient were 6.2 units which were very similar to that of our study. 22 units of packed red cells were unutilised and wasted. There is no study to compare the wasted blood in emergency setting.

\section{CONCLUSION}

- For better utilisation and to reduce wastage of blood and blood products, a protocol must be formulated.

- $\quad$ Packed red cell is the commonest blood product, which is utilised in Emergency department.

- Packed red cell transfusion is indicated in patients with haemoglobin of less than 7 grams/dL with no co-morbid conditions.

- In case there is any co-morbid condition, then transfusion has to be triggered at $7-9$ grams/dL based on the condition of the patient.
- Most common indication for platelet transfusion is viral haemorrhagic fever in Emergency department.

- Hypoproteinaemia and Alcoholic liver diseases are the commonest indication for FFP transfusion in our study.

- Massive transfusion is required in patients with acute blood loss, where all three blood components are transfused.

\section{REFERENCES}

[1] Sandeep S, Hemlata, Verma A. Adverse events related to blood transfusion. Indian $\mathrm{J}$ Anaesth 2014;58(5):543-51.

[2] Akanksha B, Surinder S, Marwaha N. Hemovigilance program-India. Asian J Transfus Sci 2013;7(1):73-4.

[3] Alcantara TY, Alresheid AA, Shammary SAMA. A comparative study on blood components utilization in selected hospital-blood banks in hail. IOSR Journal of Nursing and Health Science 2015;4(1):28-33.

[4] Klein HG, Spahn DR, Carson JL. Red blood cell transfusion in clinical practice. Lancet 2007;370(9585):415-26.

[5] Gibson BE, Todd A, Roberts I, et al. Transfusion guidelines for neonates and older children. British Journal of Haematology 2004;124(4):433-53.

[6] Sharma S, Sharma P, Tyler LN. Transfusion of blood and blood products: indications and complications. Am Fam Physician 2011;83(6):719-24.

[7] Sihler KC, Napolitano LM. Complications of massive transfusion. Chest 2010;137(1):209-20.

[8] Yaddanapudi S, Yaddanapudi LN. Indications for blood and blood product transfusion. Indian J Anaesth 2014;58(5):538-42.

[9] Amarapurkar PD, Amarapurkar DN. Management of coagulopathy in patients with decompensated liver cirrhosis. International Journal of Hepatology 2011: 1-5.

[10] Kaufman RM, Djulbegovic B, Gernsheimer T, et al. Platelet transfusion: a clinical practice guideline from the AABB. Ann Intern Med 2015;162(3):205-13.

[11] Makroo RN, Raina V, Kumar P, et al. Role of platelet transfusion in the management of dengue patients in a tertiary care hospital. Asian J Transfus Sci 2007;1(1): 4-7.

[12] Carson JL, Stanworth SJ, Roubinian N, et al. Transfusion thresholds and other strategies for guiding allogeneic red blood cell transfusion. Cochrane Database Syst Rev 2016;10:CD002042. 